\title{
PURINE METABOLISM DISORDERS AS A PREDICTOR OF TYPE 2 DIABETES MELLITUS IN THE POPULATION ${ }^{*}$
}

\author{
A. O. Chernyaeva', , M. R. Mykytyuk ${ }^{1,2}$, Yu. I. Karachentsevi, \\ O. G. Dorosh', E. M. Ashurov ${ }^{2}$ \\ ${ }^{1}$ Kharkiv Medical Academy of Postgraduate Education of the Ministry of Health of Ukraine, Kharkiv \\ ${ }^{2}$ State Institution «V. Danilevsky Institute for Endocrine Pathology Problems \\ National Academy of Medical Sciences of Ukraine", Kharkiv, Ukraine \\ annakholodnaja2008@gmail.com
}

The association between hyperuricemia (HU) and impaired glucose homeostasis (IGH) has been explored in many epidemiological studies $[1,2]$. HU was demonstrated to be considered as an independent predictor of type 2 diabetes mellitus (DM) [3, 4]. Since HU is associated with such conditions as obesity, dyslipidemia, hypertension (HT), which predictive value for type 2 diabetes is undoubted, the importance of the indirect association between HU and type 2 diabetes are under discussion. [5].

In a 'real-life' clinical setting, an individual patient develops several risk factors combination [6]. This fact allows integrating a com- mon combination of comorbidities such as obesity, hypertension, postprandial hyperglycemia (PPHG) for a symptom complex of metabolic syndrome (MS) [7]. Insulin resistance (IR) and hyperinsulinemia form an important pathogenetic component of this syndrome. HU is considered to be a component of MS and a hyperinsulinemia marker [7, 8].

To determine the significance of $\mathrm{HU}$ as a predictor of type 2 diabetes in apparently healthy individuals (according to epidemiological criteria), an analysis of the relationship of HU with all components of MS in randomized population samples was performed.

\section{MATERIAL AND METHODS}

The reporting panel was formed according to the generally accepted epidemiological approach by the randomized sampling of the workers and employees of the industrial enter- prise PJSC Novokramatorsk Machine-Building Plant. According to the agreement 1/17-K dated 03.04.2017, agreement 2/17-K dated 17.11.2017, agreement 1/18-K dated 19.02.2018 and ag-

* The article is based on the research project material «Study of the contribution of purine metabolism disorders in the development and progression of diabetes» (state registration № 0116U007261, terms 01.01.2017-31.12.2019).

The research is sponsored by the National Academy of Medical Sciences of Ukraine.

The authors guarantee the full responsibility for all published in the article.

The authors guarantee the absence of conflict of interest and own financial interest in the performance of work and writing the article.

The manuscript was received by the editorial staff 1.07.2020. 
reement 1/19-K dated 06.02.2019, between the State Institution V. Danilevsky Institute for Endocrine Pathology Problems National Academy of Medical Sciences of Ukraine and the Shopfloor union organization of the enterprise, 727 individuals were examined. The age of the subjects ranged from 18 to 65 years old, the average age of the examinees was $(38.13 \pm 5.10)$ years. Gender distribution: 457 men and 270 women. The diagnostic search was targeted at identifying those with abdominal obesity, IGH, purine metabolism disorders, dyslipidemia (hypertriglyceridemia, hypo- $\alpha$-cholesterolemia), hyperinsulinemia, and hypertension.

The presence and degree of obesity were identified by the body mass index (BMI) according to the criteria set out by the World Health Organization (WHO), 2000 [9]. BMI was calculated as the ratio of body weight in kilograms to the squared height in meters. BMI from $25.0 \mathrm{~kg} / \mathrm{m}^{2}$ to $29.9 \mathrm{~kg} / \mathrm{m}^{2}$ was estimated as an excess body weight, BMI of $30.0 \mathrm{~kg} / \mathrm{m}^{2}$ to $34.9 \mathrm{~kg} / \mathrm{m}^{2}$ as a Class 1 obesity, of $35.0 \mathrm{~kg} / \mathrm{m}^{2}$ to $39,9 \mathrm{~kg} / \mathrm{m}^{2}$ as a Class 2 obesity, BMI of 40 or higher as a Class 3 obesity. Waist circumference (WC) (cm) was measured in a vertical position of the patient in the middle of the distance between the lower edge of the chest and the iliac crest along the mid-inguinal line, and hip circumference $(\mathrm{HC})(\mathrm{cm})$ at the level of the greater trochanter, using a centimeter measuring tape. The index of the waist circumference to the hip circumference (IWC/HC) (conventional units) was calculated as the ratio of $\mathrm{WC}$ to $\mathrm{HC}$.

MS was confirmed according to a joint interim statement of the IDF, NHLBI, AHA, WHF, IAS, and IASO [10]. MS was diagnosed at the evidence of at least three of the five components:
1) abdominal obesity (WC in men $>90 \mathrm{~cm}$, in women $>80 \mathrm{~cm}$ by the IDF and WHO criteria);

2) level of triglycerides $(\mathrm{TG})>1.7 \mathrm{mmol} / \mathrm{l}$;

3) level of high-density lipoprotein cholesterol $(\mathrm{HDL}-\mathrm{C})<1.03 \mathrm{mmol} / \mathrm{l}$ in men and $<1.3 \mathrm{mmol} / 1$ in women;

4) systolic blood pressure $(\mathrm{SBP}) \geq 130 \mathrm{~mm}$ $\mathrm{Hg}$, diastolic blood pressure $(\mathrm{DBP}) \geq$ $85 \mathrm{~mm} \mathrm{Hg}$;

5) fasting blood glucose $\geq 5.56 \mathrm{mmol} / \mathrm{l}$.

The condition of glucose homeostasis was assessed according to the recommendations of the American Diabetes Association, 2012 [11]. The level of fasting glucose $\left(\mathrm{Glu}_{0}\right)(\mathrm{mmol} / \mathrm{l})$ and 120 minutes' $\left(\mathrm{Glu}_{120}\right)$ of the Oral Glucose Tolerance Test (OGTT) was determined in venous blood plasma by glucose oxidase method on the Biosen C-Line Glucose analyzer (EKF Diagnostics, Germany). Those examined who were diagnosed with fasting hyperglycemia (FHG) underwent the OGTT.

Followed 12-hour fasting, every individual was sampled for venous blood. The level of immunoreactive insulin (IRI) was determined by immune chemiluminescence technique using the $\mathrm{DRG}^{\circledR}$ Insulin ELISA Kit (USA). The severity of IR was assessed by the Homeostasis Model Assessment HOMA2 IR (conventional units), which was calculated using a certified HOMA Calculator v2.2 [12].

The concentration of total cholesterol (TC), TG, HDL-C was studied by Enzymatic Colorimetric Method: SpineLab kits (Kharkiv, Ukraine) with the universal biochemical analyzer FLUORAT ${ }^{\circledR}$-02-ABLF-T was used to determine TC and TG; the SpineLab (Kharkiv, Ukraine) set of kits for the determination of HDL-C. Low-density lipoprotein cholesterol (LDL-C), very low-density lipoprotein chole-

\section{The blood serum concentration ratio of purine metabolites in the control group}

Table 1

\begin{tabular}{c|c|c}
\hline Parameter & $\begin{array}{c}\text { Average value } \\
(\mathbf{M} \pm \mathbf{m})\end{array}$ & $\begin{array}{c}\text { Limits of the reference } \\
\text { interval }\end{array}$ \\
\hline Adenine, conventional units & $160.0 \pm 2.2$ & $90-180$ \\
\hline Guanine, conventional units & $193.0 \pm 1.2$ & $128-255$ \\
\hline Xanthine, conventional units & $142.0 \pm 0.8$ & $100-188$ \\
\hline Hypoxanthine, conventional units & $165.0 \pm 1.9$ & $104-217$ \\
\hline
\end{tabular}


Blood serum xanthine oxidase activity levels in the control group

\begin{tabular}{c|c|c|c}
\hline Parameter & $\begin{array}{c}\text { Average value } \\
\left(\overline{\mathrm{X}} \pm \mathrm{S}_{\overline{\mathrm{X}}}\right)\end{array}$ & $\begin{array}{c}\text { Limits of the } \\
\text { reference interval }\end{array}$ & $\begin{array}{c}\text { The p-value } \\
\text { of the Wilcoxon- } \\
\text { Mann-Whitney test }\end{array}$ \\
\hline $\mathrm{XO}_{\text {male, }} \mathrm{nmol} / \mathrm{min} / \mathrm{ml}$ & $2.51 \pm 0.29$ & $1.79-3.40$ & $\mathrm{p}<0.001$ \\
\hline $\mathrm{XO}_{\text {female, }} \mathrm{nmol} / \mathrm{min} / \mathrm{ml}$ & $2.50 \pm 0.19$ & $1.69-3.31$ & $\mathrm{p}<0.001$ \\
\hline
\end{tabular}

sterol (VLDL-C) concentrations and atherogenic index of plasma (AIP) were calculated according to generally accepted formulas [13].

The levels of purine metabolism intermediates (guanine, adenine, xanthine, hypoxanthine) were determined photometrically in blood serum. Metabolites of purine exchange were studied by the S.V. Oreshnikov et al. method (2008). The concentration of purine bases was expressed in extinction values (conventional units). Reference values of purine metabolites concentrations were selected by examining 25 subjects in the control group by random sampling. The normal range showed that the influence of the gender and the age of the representatives of the control group are not significant.

Uric acid (UA) levels were determined by the colorimetric method using a SpineLab, Uricase-POD (Ukraine) set of reagents. Xanthine oxidase (XO) activity was determined photometrically with the "sandwich" enzymelinked immunosorbent assay following the test system instructions of the Xanthine Oxidase Activity Assay Kit (Sigma-Aldrich, USA). The control group included 30 healthy individuals. The results obtained are presented in $\mathrm{nmol} / \mathrm{min} / \mathrm{ml}$. No statistically significant differences between the main and control groups regarding demographics were revealed. Statistical data were processed with the software package STATISTICA 7.0 (Table 2).

Blood pressure (BP) level was measured on the shoulder of the left upper extremity at the level of the heart using an Automatic blood pressure monitor (OMRON Corporation,
Japan) with a cuff of appropriate size. Blood pressure measurements were performed after 5-10 minutes of the patient at rest in a sitting position. The level of systolic (SBP) and diastolic (DBP) blood pressure was calculated as the average of two consecutive measurements. HT was diagnosed at a blood pressure level of $>$ 140/90 mm Hg [14].

The statistical analysis of the obtained data was performed with the software package Statgraphics Plus for Windows 3.0 (Manugistic Inc., USA). The Shapiro-Wilk test of normality was used to check the distribution of the variables. The Wilcoxon-Mann-Whitney test was used to compare paired variables in groups with a normal distribution of variables. The Yates' correction criterion $\left(\mathrm{x}^{2}\right)$ was used to estimate statistically the differences between the empirical and theoretical frequencies of the variation series. The correlation of abnormally distributed quantitative variables was analyzed by The Spearman's Rank Correlation Coefficient $R_{s}$. To measure the strength of the association between qualitative attributes, represented as alternative pieces of evidence, we used the Pearson coefficient of association (CA).

To determine the risk ratio of the MS components in individuals with HU compared to those with normouricemia, the relative risk value $(\mathrm{RR})$ was calculated. The null hypotheses were tested at the significance level of $\mathrm{P} \leq 0.05$. The results obtained are presented in the tables as $\overline{\mathrm{X}} \pm \mathrm{S} ; \overline{\mathrm{X}}_{ \pm} \mathrm{S}_{\overline{\mathrm{X}}}$, where $\overline{\mathrm{X}}$ is the arithmetic mean, $\mathrm{s}$ is the standard deviation, $\mathrm{S}_{\overline{\mathrm{X}}}$ is the mean deviation.

\section{RESULTS AND THEIR DISCUSSION}

IGH in a random population sample was diagnosed in 76 examined (11.8 \pm 1.4$) \%$, type 2 diabetes in 22 examined $(3.03 \pm 0.91) \%$, impaired glucose tolerance (IGT) in $47(6.5 \pm$ $0.98) \%$, fasting hyperglycemia (FHG) in 7
$(0.96 \pm 0.38) \%$ of the examined, respectively. Of the 22 patients with type $2 \mathrm{DM}$, the disease was diagnosed in 8 subjects before the examination (in three patients it was assessed as mild, in five individuals as moderate). Thus, 
IGH was diagnosed in one of those ten checked, and for each case of type 2 DM that was diagnosed earlier, about three cases of type $2 \mathrm{DM}$ de novo was seen (ratio 1:2.75), that confirms the feasibility of more active screening of the population for type 2 diabetes. Hyperinsulinemia was diagnosed in $52.6 \%$ of IGH subjects ( $\mathrm{n}=40)$ and in $22.1 \%(\mathrm{n}=161)$ of the randomized sample.

Obesity was revealed in 276 subjects, which was $(37.9 \pm 2.3) \%$. Distribution of subjects regarding the degree of obesity: Class 1 obesity $(\mathrm{n}=175)(24.1 \pm 2.1) \%$, Class 2 obesity $(\mathrm{n}=101)$ $(13.9 \pm 1.9) \%$. The dyslipidemia incidence in a random population sample was $(18.02 \pm 1.4) \%$ ( $\mathrm{n}=131)$. The diagnosed disorders were mainly dyslipidemia Type IV ( $\mathrm{n}=86)(11.8 \pm 1.1) \%$, Type IIa $(\mathrm{n}=35)(4.81 \pm 1.0) \%$ and Type IIb $(\mathrm{n}=10)(1.38 \pm 0.48) \%$.
Elevated blood pressure was diagnosed in $305(41.9 \pm 2.8) \%$ of those examined. The levels of SBP and DBP in $232(31.9 \pm 2.5) \%$ of the subjects corresponded to high normal pressure; $73(10.4 \pm 1.8) \%$ of the subjects were referred to hypertension.

HU was diagnosed in $118(16.2 \pm 1.6) \%$ of subjects having no complaints of gout, i. e. HU in these cases was asymptomatic. The studied levels of the purine metabolism condition intercorrelated: the uricemia level with concentrations of adenine $(\mathrm{r}=0.63 ; \mathrm{P}<0.001)$, guanine $(r=0.43 ; \mathrm{P}<0.001)$, hypoxanthine $(r=0.41 ; \mathrm{P}<0.001)$, xanthine $(\mathrm{r}=0.68$; $\mathrm{P}<0.001)$; XO activity with concentrations of guanine $(r=0.29 ; \mathrm{P}<0.01)$, hypoxanthine $(r=0.23 ; \mathrm{P}<0.01)$, xanthine $(r=0.28 ; \mathrm{P}<0.01)$, the uricemia level ( $r=0.86$; $\mathrm{P}<0.001)$; concentration of xanthine with concentration of ade-

Clinical and laboratory parameters

Table 3 in a random population sample regarding the uricemia level

\begin{tabular}{|c|c|c|c|}
\hline Parameter & $\begin{array}{l}\text { Individuals with } \\
\text { no hyperuricemia } \\
\text { registered } \\
(\mathrm{n}=209)\end{array}$ & $\begin{array}{c}\text { Individuals } \\
\text { with hyperuricemia } \\
(\mathrm{n}=118)\end{array}$ & $\mathbf{P}$ \\
\hline $\mathrm{BMI}, \mathrm{kg} / \mathrm{m}^{2}$ & $25.68 \pm 4.55$ & $32.4 \pm 6.01$ & $<0.001$ \\
\hline $\mathrm{WC}, \mathrm{cm}$ & $87.3 \pm 16.74$ & $100.2 \pm 13.8$ & $<0.001$ \\
\hline IWC/HC, conventional units & $0.9 \pm 0.11$ & $1.01 \pm 0.11$ & $<0.001$ \\
\hline SBP, $\mathrm{mm} \mathrm{Hg}$ & $130.2 \pm 1.4$ & $138.6 \pm 3.6$ & $<0.01$ \\
\hline $\mathrm{DBP}, \mathrm{mm} \mathrm{Hg}$ & $83.6 \pm 0.8$ & $89.2 \pm 1.4$ & $<0.01$ \\
\hline $\mathrm{Glu}_{0}, \mathrm{mmol} / \mathrm{l}$ & $5.46 \pm 0.12$ & $7.85 \pm 0.69$ & $<0.01$ \\
\hline IRI, $\mu \mathrm{U} / \mathrm{ml}$ & $18.02 \pm 8.83$ & $25.36 \pm 7.23$ & $<0.05$ \\
\hline HOMA2_IR, conventional units & $2.37 \pm 1.12$ & $3.69 \pm 1.39$ & $<0.01$ \\
\hline Cholesterol, $\mathrm{mmol} / \mathrm{l}$ & $5.09 \pm 0.77$ & $6.01 \pm 1.28$ & $<0.01$ \\
\hline HDL-C, mmol/l & $1.36 \pm 0.32$ & $1.12 \pm 0.24$ & $<0.02$ \\
\hline $\mathrm{TG}, \mathrm{mmol} / \mathrm{l}$ & $1.11 \pm 0.34$ & $2.06 \pm 0.52$ & $<0.0001$ \\
\hline $\mathrm{LDL}-\mathrm{C}, \mathrm{mmol} / \mathrm{l}$ & $3.06 \pm 0.12$ & $3.47 \pm 0.14$ & $<0.001$ \\
\hline VLDL-C, mmol/l & $0.20 \pm 0.01$ & $0.30 \pm 0.03$ & $<0.001$ \\
\hline AIP, conventional units & $2.67 \pm 0.06$ & $3.42 \pm 0.23$ & $<0.05$ \\
\hline UA in blood, $\mu \mathrm{mol} / \mathrm{l}$ & $282.6 \pm 2.8$ & $418.0 \pm 8.2$ & $<0.001$ \\
\hline Adenine, conventional units & $116.0 \pm 2.6$ & $163.0 \pm 6.0$ & $<0.001$ \\
\hline Guanine, conventional units & $168.4 \pm 1.4$ & $281.1 \pm 4.3$ & $<0.001$ \\
\hline Xanthine, conventional units & $125.6 \pm 0.5$ & $178.6 \pm 0.3$ & $<0.001$ \\
\hline $\begin{array}{l}\text { Hypoxanthine, } \\
\text { conventional units }\end{array}$ & $153.6 \pm 1.2$ & $208.8 \pm 1.6$ & $<0.001$ \\
\hline $\mathrm{XO}$ activity, $\mathrm{nmol} / \mathrm{min} / \mathrm{ml}$ & $2.56 \pm 0.19$ & $3.58 \pm 0.30$ & $<0.01$ \\
\hline
\end{tabular}


Spearman's rank correlation coefficients

between the purine metabolism values and clinical and biochemical parameters of the examined subjects

\begin{tabular}{|c|c|c|c|}
\hline Parameter & Factor & $\mathbf{r}_{\mathrm{s}}$ & $\mathbf{P}$ \\
\hline \multirow{3}{*}{ Adenine, conventional units } & $\mathrm{BMI}, \mathrm{kg} / \mathrm{m}^{2}$ & 0.32 & 0.001 \\
\hline & $\mathrm{TG}, \mathrm{mmol} / \mathrm{l}$ & 0.36 & 0.001 \\
\hline & $\mathrm{Glu}_{0}, \mathrm{mmol} / \mathrm{l}$ & 0.22 & $<0.05$ \\
\hline Guanine, conventional units & Age, years & 0.19 & 0.05 \\
\hline \multirow{2}{*}{ Xanthine, conventional units } & $\mathrm{BMI}, \mathrm{kg} / \mathrm{m}^{2}$ & 0.27 & 0.001 \\
\hline & $\mathrm{TG}, \mathrm{mmol} / \mathrm{l}$ & 0.32 & 0.001 \\
\hline \multirow{9}{*}{ UA in blood, $\mu \mathrm{mol} / \mathrm{l}$} & Age, years & 0.17 & 0.01 \\
\hline & $\mathrm{BMI}, \mathrm{kg} / \mathrm{m}^{2}$ & 0.37 & 0.001 \\
\hline & $\mathrm{SBP}, \mathrm{mm} \mathrm{Hg}$ & 0.24 & 0.01 \\
\hline & $\mathrm{DBP}, \mathrm{mm} \mathrm{Hg}$ & 0.18 & 0.01 \\
\hline & $\mathrm{HDL}-\mathrm{C}, \mathrm{mmol} / \mathrm{L}$ & -0.16 & $<0.05$ \\
\hline & $\mathrm{TG}, \mathrm{mmol} / \mathrm{l}$ & 0.28 & 0.001 \\
\hline & $\mathrm{Glu}_{0}, \mathrm{mmol} / \mathrm{l}$ & 0.51 & 0.001 \\
\hline & $\mathrm{Glu}_{120}, \mathrm{mmol} / \mathrm{l}$ & 0.59 & 0.001 \\
\hline & IRI, $\mu \mathrm{U} / \mathrm{ml}$ & 0.31 & 0.01 \\
\hline \multirow{2}{*}{$\mathrm{XO}$ activity, $\mathrm{nmol} / \mathrm{min} / \mathrm{ml}$} & $\mathrm{DBP}, \mathrm{mm} \mathrm{Hg}$ & 0.29 & 0.001 \\
\hline & $\mathrm{TG}, \mathrm{mmol} / \mathrm{l}$ & 0.31 & 0.001 \\
\hline
\end{tabular}

nine $(\mathrm{r}=0.90 ; \mathrm{P}<0.001)$, guanine $(\mathrm{r}=0.36$; $\mathrm{P}<0.001)$, hypoxanthine $(\mathrm{r}=0.46 ; \mathrm{P}<0.001)$; hypoxanthine concentration with adenine concentration $(\mathrm{r}=0.86 ; \mathrm{P}<0.001)$.

The obtained positive statistically significant linear associations of purine metabolism intermediates between each other and its final product uric acid (UA) with the XO activity $\mathrm{XO}$ indicate that $\mathrm{HU}$ in a random population sample is mainly metabolic in nature, i.e. due to excessive production of UA in the body. It is known that in nephrogenic HU high concentration of UA in the blood is not due to an increased breakdown of purines but results from insufficient excretion of urates by the kidneys [15]. In this case, a no proportional increase in the XO activity and purine metabolism intermediates is needed.

The predominantly metabolic genesis of $\mathrm{HU}$ in the examined random population sample is suggested by the established correlation of $\mathrm{HU}$ with the main components of MS (Table 3).

At the next stage of the study, to assess the relationship of hyperuricemic disorders of purine metabolism with the "classic» predictors of type 2 diabetes, the correlation of the uricemia level, purine metabolism intermediates and clinical and hormonal parameter values (age, BMI, WC, SBP, DBP, Glu , Glu $_{120}$, IRI, TG and HDL-C in the blood) was analyzed (Table 4).

As shown in Table 4, the concentration of adenine as one of the initial substrates of purine catabolism is positively associated with the level of $\mathrm{Glu}_{0}$, while the final product of purine metabolism UA correlates so with the level of $\mathrm{Glu}_{0}$ and IRI. The association between uricemia levels and $\mathrm{Glu}_{120}$ levels and IRI may indicate that IR enables the preconditions for intensified purine catabolism and increased UA production.

It is known that type 2 diabetes is associated with obesity, dyslipidemia, hyperinsulinemia, and IR [16-18]. Each of the above mentioned morbid conditions is associated with HU, even with no obligatory evidence of IGH [19]. In view of this, it can be assumed that HU may be related not so much to IGH but to the other components of MS being present. Among the MS components, some authors emphasize 
Analysis of the MS components frequency seen in the subjects with the regard for the uricemia level

\begin{tabular}{|c|c|c|c|c|}
\hline $\begin{array}{l}\text { Morbid } \\
\text { condition }\end{array}$ & $\begin{array}{c}\text { Individuals } \\
\text { with HU } \\
(\mathrm{n}=118)\end{array}$ & $\begin{array}{l}\text { No HU revealed } \\
(\mathrm{n}=609)\end{array}$ & $\begin{array}{c}\text { The } x^{2} \text { criterion } \\
\text { value }\end{array}$ & $\mathbf{P}$ \\
\hline \multirow{3}{*}{$\begin{array}{l}\text { Obesity: } \\
\text { Class } 1 \\
\text { Class } 2\end{array}$} & $\mathrm{n}=75 / 63.56$ & $\mathrm{n}=201 / 33.00 \%$ & 37.90 & 0.001 \\
\hline & $\mathrm{n}=41 / 34.70 \%$ & $\mathrm{n}=134 / 22.00 \%$ & 8.09 & 0.005 \\
\hline & $\mathrm{n}=34 / 28.81 \%$ & $\mathrm{n}=67 / 11.00 \%$ & 24.75 & 0.001 \\
\hline \multirow{2}{*}{ Increased BP: } & $\mathrm{n}=78 / 66.10 \%$ & $\mathrm{n}=227 / 37.27 \%$ & 32.56 & 0.001 \\
\hline & $\mathrm{n}=47 / 39.80 \%$ & $\mathrm{n}=160 / 26.27 \%$ & 8.27 & 0.005 \\
\hline $\begin{array}{c}\text { High BP } \\
\text { Normal BP } \\
\text { HT }\end{array}$ & $\mathrm{n}=31 / 26.27 \%$ & $\mathrm{n}=67 / 11,00 \%$ & 22.18 & 0.001 \\
\hline \multirow{3}{*}{$\begin{array}{l}\text { IGH: } \\
\text { FHG } \\
\text { IGT }\end{array}$} & $\mathrm{n}=44 / 37.29 \%$ & $\mathrm{n}=32 / 5,25 \%$ & 104.96 & 0.001 \\
\hline & $\mathrm{n}=5 / 4.24 \%$ & $\mathrm{n}=2 / 0.33 \%$ & 12.00 & 0.001 \\
\hline & $\mathrm{n}=25 / 21.19 \%$ & $\mathrm{n}=22 / 3.61 \%$ & 47.62 & 0.001 \\
\hline $\begin{array}{c}\text { Type } 2 \mathrm{DM} \\
\text { de novo }(\mathrm{n}=14)\end{array}$ & $\mathrm{n}=8 / 6.78 \%$ & $\mathrm{n}=6 / 0.99 \%$ & 14.64 & 0.001 \\
\hline \multirow{4}{*}{$\begin{array}{c}\text { Dyslipidemia: } \\
\text { Type IIa } \\
\text { Type IIb } \\
\text { Type IV }\end{array}$} & $\mathrm{n}=32 / 27.12 \%$ & $\mathrm{n}=99 / 16.26 \%$ & 7.18 & 0.008 \\
\hline & $\mathrm{n}=8 / 6.78 \%$ & $\mathrm{n}=25 / 4.11 \%$ & 1.07 & 0.3 \\
\hline & $\mathrm{n}=3 / 2.54 \%$ & $\mathrm{n}=8 / 1.31 \%$ & 0.35 & 0.56 \\
\hline & $\mathrm{n}=22 / 18.64 \%$ & $\mathrm{n}=66 / 10.84 \%$ & 4.95 & 0.027 \\
\hline
\end{tabular}

the particular importance of obesity as an intermediator between $\mathrm{HU}$ and type 2 diabetes [20]. The comparison of the frequency of the MS individual components under HU shows that obesity $(63.56 \%)$ and elevated blood pressure $(66.1 \%)$ are revealed to contribute most to the most hyperuricemia (table 5).

To determine the HU and the MS components relationship, both their frequency and the HU risk at each MS individual component being revealed, were assessed. That is, the more significantly the HU increases the relative risk of the onset of MS individual components, the more important should be its value for them as a risk factor. Yet, obesity and hypertension, the frequency of which is high for HU subjects, were present in those subjects with no HU evidence (33.00 and $37.27 \%$, respectively). It was found that the risk of obesity is the following: in people with HU: RR 2.85 (95\% confidence interval (CI) (2.02-4.02); hypertension RR 2.29 (95\% CI (1.61-3.25); IGH RR 5.09 (95\% CI (3.82-6.79); type 2 diabetes RR 3.7 (95\% CI (2.28-6.02); and dyslipidemia RR 1.69 (95\% CI (1.18-2.42), respectively.
Based on the calculation of CA between HU and MS components, it was found that among all MS components, the following are associated with HU: IGH, obesity, hyperinsulinemia, hypertension, and dyslipidemia type IV. Herewith, the statistical value of $\mathrm{HU}$ as a risk factor for IGH (IGT + type 2 diabetes) is the most significant $(\mathrm{CA}=0.64)$, which indicates a close relationship between hyperuricemic disorders of purine metabolism and IGH; for the Class 2 obesity $(\mathrm{CA}=0.52)$, hyperinsulinemia $(\mathrm{CA}=0.59)$, hypertension $(\mathrm{CA}=0.48)$, and type IV dyslipidemia $(\mathrm{CA}=0.51)$, the statistical association with HU was moderate.

Thus, as a result of the study, the frequency of HU (16.2\%) and IGH (11.8\%) in a random population sample was assessed. Positive statistically significant linear associations of the concentration of purine metabolism intermediates and uric acid with xanthine oxidase activity indicate the predominantly metabolic nature of hyperuricemia in the examined subjects of the randomized population. The revealed relative risk of glucose homeostasis impairment in the subjects with diagnosed hyperuricemia is 
5.09 (95\% CI (3.82-6.79), type 2 diabetes 3.7 (95\% CI (2.28-6.02). Among all MS components, the statistical value of hyperuricemia as a risk factor is the most significant for glucose homeostasis disorders (type 2 diabetes and impaired glucose tolerance $(\mathrm{CA}=0.64)$.

\section{CONCLUSIONS}

1. In a random population sample, impaired glucose homeostasis was diagnosed in $11.8 \%$ of subjects (including type 2 diabetes in $3.03 \%$, impaired glucose tolerance in $6.50 \%$, fasting hyperglycemia in $0.96 \%$, respectively).

2 . It was found that for each case of type 2 diabetes that was diagnosed earlier, there are about three cases of type 2 diabetes de novo (ratio 1:2.75), which confirms the feasibility of more active screening of the population for type $2 \mathrm{DM}$.

3. Asymptomatic hyperuricemia was diagnosed in $16.20 \%$ of the examined subjects.

4. Positive statistically significant linear associations between the concentration of purine metabolism intermediates and uric acid with xanthine oxidase activity indicate a predominantly metabolic nature of hyperuricemia in the subjects of a random population sample.

5. It is established that the relative risk of impaired glucose homeostasis in subjects with confirmed hyperuricemia is 5.09 (95\% CI (3.82-6.79), type 2 diabetes 3.7 (95\% CI (2.28-6.02), respectively.

6. Among all components of the metabolic syndrome, the statistical significance of hyperuricemia as a risk factor is the most significant for disorders of glucose homeostasis (type 2 diabetes and impaired glucose tolerance $(\mathrm{CA}=0.64)$.

\section{REFERENCES}

1. Van der Schaft N, Brahimaj A, Wen KX, et al. PLoS One 2017; 12(6): e0179482. doi:10.1371/journal.pone.0179482.

2. Bombelli M, Quarti-Trevano F, Tadic M, et al. J Hypertens 2018; 36(7): 1492-1498. doi:10.1097/HJH.00000000 00001721 .

3. Dehghan A, van Hoek M, Sijbrands EJ, et al. Diabetes Care 2008; 31(2): 361-362. doi.org/10.2337/ dc07-1276.

4. Wang T, Bi Y, Xu M, et al. Endocrine 2011; 40(1): 109116. doi.org/10.1007/s12020-011-9449-2.

5. Wu AH, Gladden JD, Ahmed M, et al. Int J Cardiol 2016; 213: 4-7. doi.org/10.1016/j.ijcard.2015.08.110.

6. Bardin T, Richette P. BMC Med 2017; 15(1): 123. doi:10. 1186/s12916-017-0890-9

7. McCracken E, Monaghan M, Sreenivasan S. Clin Dermatol 2018; 36(1): 14-20. doi:10.1016/j.clindermatol.2017. 09.004 .

8. Gluvic Z, Zaric B, Resanovic I, et al. Curr Vasc Pharmacol 2017; 15(1): 30-39. doi:10.2174/157016111466616 1007164510 .

9. WHO. Obesity: Preventing and managing the global epidemic : Report of a WHO Consultation, Geneva, 2000: 252 p.

10. Alberti KG, Eckel RH, Grundyet SM, et al. Circulation 2009; 120: 1640-1645.
11. American Diabetes Association. Diabetes Care 2012; 35(1): S.64-S.71.

12. HOMA Calculator. The Oxford Centre for Diabetes, Endocrinilogy and Metabolism, available at: www.dtu. ox.ac.uk/homacalculator/index.php.

13. Klimov AN, Nikul'cheva JuG. Obmen lipidov i lipoproteidov i ih narushenija, Sankt-Peterburg, 1999: 505 p.

14. ESC/ESH Guidelines for the management of arterial hypertension. Rev Esp Cardiol (Engl Ed) 2019; 72(2): 160. doi:10.1016/j.rec.2018.12.004.

15. Mallat SG, Kattar S, Tanios BY, et al. Curr Hypertens Rep 2016; 18(10): 74. doi: 10.1007/s11906-016-0684-z.

16. Henning RJ. Future Cardiol 2018; 14(6): 491-509. doi: 10.2217/fca-2018-0045.

17. Kuwabara M, Kuwabara R, Hisatome I, et al. J Obesity (Silver Spring) 2017; 25(11): 1997-2008. doi: 10.1002/ oby. 22000 .

18. Hou YL, Yang XL, Wang CX, et al. Lipids Health Dis 2019; 18(1): 81. doi: 10.1186/s12944-019-1031-6.

19. Li L, Song Q, Yang X. J Diabetes Res 2019; 4: 29. doi: 10.1155/2019/3175418.

20. Ali N, Perveen R, Rahman S, et al. PLoS One 2018; 13(11): e0206850. doi: 10.1371/journal.pone.0206850. 


\title{
PURINE METABOLISM DISORDERS AS A PREDICTOR OF TYPE 2 DIABETES MELLITUS IN THE POPULATION
}

\author{
A. O. Chernyaeva ${ }^{1,2}$, M. R. Mykytyuk ${ }^{1,2}$, Yu. I. Karachentsev ${ }^{1,2}$, \\ O. G. Dorosh ${ }^{2}$, E. M. Ashurov² \\ ${ }^{1}$ Kharkiv Medical Academy of Postgraduate Education of the Ministry of Health of Ukraine, Kharkiv \\ ${ }^{2}$ State Institution «V. Danilevsky Institute for Endocrine Pathology Problems \\ National Academy of Medical Sciences of Ukrainen, Kharkiv, Ukraine \\ annakholodnaja2008@gmail.com
}

To determine the significance of hyperuricemia (HU) as a predictor of type 2 diabetes mellitus (DM) in apparently healthy (according to epidemiological criteria) individuals, an analysis of the relationship between elevated uric acid (UA) in the blood and all components of the metabolic syndrome (MS) was performed in randomized population samples.

Material and methods. The reporting panel was formed according to the generally accepted epidemiological approach by the randomized sampling of the workers and employees of the industrial enterprise ( $\mathrm{n}=727$ people). The age of the subjects ranged from 18 to 65 years; the average age was (38.13 \pm 5.1$)$ years. MS was confirmed by the IDF criteria. The glucose homeostasis condition was assessed according to the ADA recommendations. The purine metabolites were studied by the S. V. Oreshnikov et al. method (2008). The levels of uric acid were determined by the colorimetric method, xanthine oxidase activity by the photometric method. Anthropometric parameters, glycemia, immunoreactive insulin, blood lipid profile were studied, blood pressure was measured.

Results and their discussion. In a random population sample, impaired glucose homeostasis was diagnosed in $11.8 \%$ of subjects (including those with type 2 diabetes in $3.03 \%$ cases, impaired glucose tolerance $6.50 \%$, fasting hyperglycemia $0.96 \%$, respectively). It was found that for each diagnosed earlier patient with type 2 diabetes, about three cases of type 2 diabetes de novo (ratio 1:2.75) are revealed, which confirms the feasibility of more active screening of the population for type 2 DM. Asymptomatic hyperuricemia was diagnosed in $16.2 \%$ of the examined subjects. Positive statistically significant linear associations of the concentration of purine metabolism intermediates among them and UA with xanthine oxidase activity indicate a predominantly metabolic nature of hyperuricemia in the subjects of the randomized sample. The relative risk of impaired glucose homeostasis in subjects with established hyperuricemia is found to be 5.09 (95\% CI (3.82-6.79), type 2 diabetes 3.7 (95\% CI (2.28-6.02) Among all components of MS, the statistical value of hyperuricemia as a risk factor is the most significant for the disorders of glucose homeostasis (type 2 diabetes and impaired glucose tolerance $(\mathrm{CA}=0.64)$

Keywords: purine metabolism, impaired glucose homeostasis, type 2 diabetes mellitus, metabolic syndrome, uric acid.

\section{ПОРУШЕННЯ ПУРИНОВОГО ОБМІНУ ЯК ПРЕДИКТОР ЦУКРОВОГО ДІАБЕТУ 2 ТИПУ В ПОПУЛЯЦІЇ}

\author{
Черняева А.О. ${ }^{1,2}$, Микитюк М.P. ${ }^{1.2}$, Караченцев Ю.І. ${ }^{1,2}$, \\ Дорош О. Г. ${ }^{2}$, Ашуров Е.M. ${ }^{2}$ \\ ${ }^{1}$ Харківська медична акаделія післядиплолної освіти МОЗ України, м. Харків, Україна; \\ ${ }^{2}$ ДУ «Інститут проблем ендокринної патологї ім. В. Я. Данилевського НАМН України», \\ м. Харків, Украӥна \\ annakholodnaja2008@gmail.com
}

3 метою з'ясування значення гіперурикемії як предиктора цукрового діабету (ЦД) 2 типу у практично здорових осіб (за епідеміологічними критеріями), було проведено аналіз зв'язку підвищеного рівня сечової кислоти (CК) в крові з усіма компонентами метаболічного синдрому (MC) у випадкових популяційних вибірках.

Матеріали і методи. Група обстежених сформована за загальноприйнятими епідеміологічними підходами методом випадкової вибірки з числа робочих і службовців промислового підприемства (n = 727 осіб). Вік обстежених від 18 до 65 років, середній - $(38,13 \pm 5,1)$ років. МС верифікували за критеріями IDF. Оцінку стану гомеостазу глюкози здійснювали згідно рекомендацій ADA. Метаболіти пуринового обміну досліджували методом С. В. Орешнікова та співавт. (2008р.). Рівні СК визначали колориметричним методом, активність ксантиноксидази - фотометричним методом. Досліджували антропометричні показники, рівень глікемії, імунореактивного інсуліну, ліпідний спектр крові, вимірювали артеріальний тиск.

Результати і їх обговорення. У випадковій популяційній вибірці порушення глюкозного гомеостазу діагностовано у 11,8\% обстежених (в тому числі ЦД 2 типу у 3,03\%, порушення толерантності до глюкози - 6,5\%, гіперглікемію натще - у 0,96\%, відповідно). Встановлено, що на кожний випадок ЦД 2 типу, який було діагностовано раніше, припадає близько трьох випадків ЦД 2 типу de novo (співвідношення 1:2,75), що підтверджуе доцільність більш активного скринінгу населення на ЦД 2 типу. Асимптоматичну гіперурикемію діагностовано у 16,2\% обстежених. Позитивні статистично значущі лінійні асоціації концентрації інтермедіатів пуринового обміну між собою і СК з активністю 
ксантиноксидази вказують на переважно метаболічну природу гіперурикемії у обстежених випадкової популяційної вибірки. Встановлено, що відносний ризик порушень глюкозного гомеостазу у обстежених з верифікованою гіперурикеміею становить 5,09 (95\% CI (3,82-6,79), ЦД 2 типу - 3,7 (95\% CI $(2,28-6,02)$, відповідно. Серед усіх компонентів MC статистична значущість гіперурикемії як фактору ризику найбільш вагома для порушень глюкозного гомеостазу (ЦД 2 типу і порушення толерантності до глюкози $(\mathrm{KA}=0,64)$.

Кл ючові слов а: пуриновий обмін, порушення глюкозного гомеостазу, цукровий діабет 2 типу, метаболічний синдром, сечова кислота

\title{
НАРУШЕНИЕ ПУРИНОВОГО ОБМЕНА КАК ПРЕДИКТОР САХАРНЫМ ДИАБЕТОМ 2 ТИПА В ПОПУЛЯЦИИ
}

\author{
Черняева А. О. ${ }^{1,2}$, Микитюк М. Р. ${ }^{1.2}$, Караченцев Ю. И. ${ }^{1,2}$, \\ Дорош Е. Г. ${ }^{2}$, Ашуров Э. М. ${ }^{2}$ \\ ${ }^{1}$ Харковская медицинская акаделия последиплолного образования МЗ Украины, \\ г. Харьков, Украина; \\ ${ }^{2}$ ГУ "Институт проблем эндокринной патологии ил. В. Я. Данилевского НАМН Украинь», \\ г. Харьков, Украина \\ annakholodnaja2008@gmail.com
}

С целью выяснения значения гиперурикемии как предиктора сахарного диабета (СД) 2 типа у практически здоровых лиц (по эпидемиологическим критериям), был проведен анализ связи повышенного уровня мочевой кислоты (МК) в крови со всеми компонентами метаболического синдрома (MC) в случайных популяционных выборках.

Материалы и методы. Группа обследованных сформирована по общепринятым эпидемиологическим подходам методом случайной выборки из числа рабочих и служащих промышленного предприятия ( $\mathrm{n}=727$ человек). Возраст обследованных от 18 до 65 лет, средний - $(38,13 \pm 5,1)$ лет. МС верифицировали по критериям IDF. Оценку состояния гомеостаза глюкозы осуществляли согласно рекомендациям ADA. Метаболиты пуринового обмена исследовали методом С. В. Орешникова и соавт. (2008 г.). Уровни МК определяли колориметрическим методом, активность ксантиноксидазы - фотометрическим методом. Исследовали антропометрические показатели, уровни гликемии, иммунореактивного инсулина, липидный спектр крови, измеряли артериальное давление.

Результаты и их обсуждение. В случайной популяционной выборке нарушения глюкозного гомеостаза диагностирован у 11,8\% обследованных (в том числе СД 2 типа в 3,03\%, нарушение толерантности к глюкозе - 6,5\%, гипергликемия натощак - в 0,96\%, соответственно). Установлено, что на каждый случай СД 2 типа, который был диагностирован ранее, приходится около трех случаев СД 2 типа de novo (соотношение $1: 2,75)$, что подтверждает целесообразность более активного скрининга СД 2 типа у населения. Асимптоматическая гиперурикемия диагностирована у 16,2\% обследованных. Положительные статистически значимые линейные ассоциации концентрации интермедиаторов пуринового обмена между собой и МК с активностью ксантиноксидазы указывают на преимущественно метаболическую природу гиперурикемии у обследованных случайной популяционной выборки. Установлено, что относительный риск нарушений глюкозного гомеостаза у обследованных с верифицированной гиперурикемией составляет 5,09 (95\% CI (3,82-6,79), СД 2 типа - 3,7 (95\% CI (2,28-6,02), соответственно. Среди всех компонентов МС статистическая значимость гиперурикемии как фактора риска наиболее весомая для нарушений глюкозного гомеостаза (СД 2 типа и нарушения толерантности к глюкозе $($ КА $=0,64)$.

Ключевые слова: пуриновый обмен, нарушение глюкозного гомеостаза, сахарный диабет 2 типа, метаболический синдром, мочевая кислота. 